\title{
IMPLEMENTASI PERATURAN MENTERI HUKUM DAN HAM NOMOR 23 TAHUN 2018 TENTANG PENGHARMONISASIAN RANCANGAN PERATURAN MENTERI, RANCANGAN PERATURAN LEMBAGA PEMERINTAH NON KEMENTERIAN ATAU RANCANGAN PERATURAN DARI LEMBAGA NON STRUKTURAL OLEH PERANCANG PERATURAN PERUNDANG-UNDANGAN
}

\author{
(Application of the Regulation of the Minister of Law and Human Rights no. 23 of 2018 \\ Regarding Harmonization of the Drafts of the Regulations of Ministers, Non-Ministry \\ Government Agencies or Non-Structural Agencies by the Laws Drafter)
}

\author{
Firdaus; Donny Michael \\ Pusat Penelitian dan Pengembangan Hak Asasi Manusia \\ Badan Penelitian dan Pengembangan Hukum dan Hak Asasi Manusia \\ Jl. H.R. Rasuna Said Kav. 4-5, Kuningan Jakarta Selatan 12940 \\ firdaus_ham@yahoo.co.id; dmsitumorang@yahoo.com
}

Tulisan Diterima: 27 Juni 2019; Direvisi: 11 September 2019; Disetujui Diterbitkan 12 September 2019

DOI: $\underline{\text { http://dx.doi.org/10.30641/dejure.2019.V19.323-338 }}$

\begin{abstract}
The issuance of the Regulation of the Minister of Law and Human Rights No. 23 of 2018 regarding Harmonization of the Draft of Regulations of the Ministers, Non-Ministry Government Agencies and NonStructural Agencies by the Law Drafter has given a raise to some pros and cons. One of the cons addresses that this Regulation of the Minister of Law and Human Rights was considered against the Law No. 12 of 2011 regarding the Establishment Legislations. The questions raised by this research are : (i) whether or not the establishment has been in compliance with the existing legislation and (ii) the effectiveness of the implementation. The objectives of this research are: (i) to confirm the validity of its establishment process; and (ii) to find out whether the implementation of the Regulation of the Minister of Law and Human Rights No. 23 of 2018 has been effected in connection with the harmonization of the drafts of regulations of the ministries and other agencies by the drafters of legislations. According to the research, a fact has been disclosed that the Regulation of the Minister of Law and Human Rights No. 23 of 2018 has been contradicting against the higher laws and regulations and the harmonization of legislations limited up to the laws and President Regulations. This research is a normative legal research with juridical descriptive analysis, while this research systematically describe the entire issues of the researched object by analyzing the collected data, both primary legal data and secondary legal data. This study also employs empirical research methods, in which this research also analyzes the implementation of material law applied to the legal subjects.
\end{abstract}

Keywords: implementation; regulation; harmonization; effectiveness.

\begin{abstract}
ABSTRAK
Dengan diundangkannya Peraturan Menteri Hukum dan HAM No. 23 Tahun 2018 tentang Pengharmonisasian Rancangan Peraturan Menteri, Rancangan Peraturan Lembaga Pemerintah Nonkementerian, dan Rancangan Peraturan dari Lembaga Nonstruktural oleh Perancang Peraturan Perundang-undangan telah menuai pro dan kontra.Salah satu kontra adalah bahwa Permenkumham ini dinilai bertentangan dengan Undang-Undang Nomor 12 Tahun 2011 tentang Pembentukan Peraturan
\end{abstract}


Perundang-Undangan.Rumusan masalah dalam penelitian ini adalah: (i) Apakah pembentukannya telah sesuai dengan peraturan perundang-undangan? dan (ii) Bagaimana efektivitas pelaksanaannya? Tujuan penelitian ini adalah: (i) untuk mengetahui keabsahan proses pembentukannya; dan (ii) untuk mengetahui efektivitas pelaksanaannya Permenkumham No. 23 Tahun 2018 terkait pengharmonisasian peraturan rancangan kementerian dan lembaga oleh perancang peraturan perundang-undangan. Berdasarkan penelitian ini, maka ditemukan fakta bahwa Permenkumham No.23 Tahun 2018 bertentangan dengan peraturan perundang-undangan yang lebih tinggi dan pengharmonisasi peraturan perundang-undangan dengan limitasi sampai pada tingkatan undang-undang hingga Peraturan Presiden. Penelitian ini merupakan penelitian hukum normatif yuridis yang bersifat deskriptif analitis, dimana penelitian ini menggambarkan secara keseluruhan obyek yang diteliti secara sistematis dengan menganalisis data-data yang diperoleh baik data hukum primer dan data hukum sekunder. Penelitian ini juga menggunakan metode penelitian empiris, di mana penelitian ini menganalisis implementasi hukum materil yang diberlakukan kepada subjek hukum.

Kata kunci: implementasi; peraturan; harmonisasi; efektivitas.

\section{PENDAHULUAN}

Peraturan perundang-undangan merupakan bagian dari sistem hukum nasional yang sangat berperan dalam pembangunan hukum nasional untuk mewujudkan sistem hukum yang berdasarkan Pancasila dan Undang-Undang Dasar 1945. Adapun arah kebijakan harmonisasi peraturan perundang-undangan tersebut menjadi arahan untuk melaksanakan harmonisasi peraturan perundangundangan. Undang-Undang Republik Indonesia Nomor 12 Tahun 2011 Tentang Pembentukan Peraturan Perundang-undangan menyatakan bahwa pengharmonisasian, pembulatan, dan pemantapan konsepsi rancangan undang-undang, rancangan peraturan pemerintah, dan rancangan peraturan presiden dikoordinasikan oleh menteri yang menyelenggarakan urusan pemerintahan di bidang hukumserta jenis peraturan perundang-undangan yang diakui keberadaannya dan mempunyai kekuatan hukum mengikat sepanjang diperintahkan oleh peraturan perundang-undangan yang lebih tinggi atau dibentuk berdasarkan kewenangan lainnya. ${ }^{1}$

Dengan demikian urgensi pengharmonisasian peraturan perundang-undangan saat ini semakin lama menjadi semakin signifikan di tengah situasi dan kondisi yang semakin kompleks. Signifikansi yang paling mengemuka terhadap langkah-langkah harmonisasi peraturan perundang-undangan adalah untuk terciptanya kepastian dan jaminan hukum bagi setiap individu/orang yang berkepentingan.

1 Lihat Pasal 7 dan 8 Undang-Undang Republik Indonesia Nomor 12 Tahun 2011 tentang Pembentukan Peraturan Perundang-Undangan
Sehingga tanpa adanya harmonisasi peraturan perundang-undangan yang sedang disusun, akan memunculkan ketidak pastian hukum, ketidak tertiban dan rasa tidak dilindunginya masyarakat. Dalam perspektif demikian masalah kepastian hukum akan dirasakan sebagai kebutuhan yang hanya dapat terwujud melalui harmonisasi peraturan perundang-undangan.

Pengharmonisasian peraturan perundangundangan dapat dilakukan dalam dua langkah perumusan, yaitu (i) harmonisasi kebijakan formulasi (sistem pengaturan) dan (ii) harmonisasi materi (subtansi). Hal pertama menunjuk pada langkah perumusan harmonisasi sistem hukum, dan hal kedua menunjuk pada langkah perumusan harmonisasi norma-norma (materi hukum), namun demikian dapat dikatakan pengharmonisasian peraturan perundang-undangan dirumuskan dalam dua langkah yaitu penyesuaian sistem hukum nasional menjadi sistem hukum yang bersifat global dan harmonis sebagai hukum positif (harmonyof law) dan penyesuaian norma-norma hukum tertentu menjadi satu kesatuan norma yang bersifat global.

Menurut Lawrence M. Friedman, perumusan langkah yang ideal dalam harmonisasi peraturan perundang-undangan adalah dengan melakukan penyesuaian unsur-unsur tatanan hukum yang berlaku dalam rangka sistem hukum nasional yang mencakup materi hukum (legal substance), struktur hukum (legal structure) dan budaya hukum (legal culture). ${ }^{2}$

2 Lawrence M Friedman, American Law: An Introduction (Hukum Amerika: Sebuah Pengantar), 
Kondisi ketidak harmonisan antar undangundang dan ketentuan yang multitafsir dapat disebabkan oleh kuatnya pengaruh politik dalam pembentukan perundang-undangan. Proses pembentukan perundang-undangan terkadang tidak mempertimbangkan teori, prinsip, dan asas hukum, tetapi lebih banyak unsur kepentingan tertentu yang seharusnya pembentukan hukum tidak dapat dipengaruhi oleh situasi politik. Kondisi tersebut berdampak pada penafsiran yang berbeda pada pemangku kepentingan yang terkait dengan suatu peraturan perundang-undangan dan masyarakat. Penafsiran yang beragam tersebut akan menimbulkan sulitnya implementasi undangundang dan inkonsistensi dalam penegakan hukum.

Permasalahan pelaksanaan peraturan perundang-undangan akhir-akhir ini menjadi isu yang sangat mengemuka. Terjadinya tumpang tindih dan peraturan perundang-undangan yang sederajat dengan peraturan perundang-undangan tingkat pusat menjadi isu yang selalu diangkat dalam berbagai kesempatan. Pada dasarnya semua aparatur penyelenggaraan negara sangat menyadari terjadinya hal tersebut, namun tindak lanjut untuk mengantisipasi permasalahan tersebut tidak pernah tuntas. Salah satu penyebabnya adalah masih terjadinya ego sektoral atau kepentingan dari kementerian/lembaga (K/L) yang sebenarnya sangat dibutuhkan agar dapat meminimalisasi terjadinya ketidak seimbangan dari pelaksanaan penyusunan peraturan perundang-undangan.

Selama ini, banyak peraturan menteri dan lembaga negara pada tingkat penyusunan Rancangan Peraturan Menteri, Peraturan Lembaga Nonkementerian, atau Lembaga Nonstruktural sering menimbulkan masalah dan tumpang tindih serta bersinggungan satu dengan lainnya yang mendorong Sehingga Direktorat Jenderal Peraturan Perundang-Undangan Kementerian Hukum dan HAM untuk membentuk Peraturan Menteri Hukum dan HAM Nomor 23 Tahun 2018 tentang Pengharmonisasian Rancangan Peraturan Menteri, Rancangan Peraturan Lembaga Pemerintah Nonkementerian, dan Rancangan Peraturan dari Lembaga Nonstruktural oleh Perancang Peraturan Perundang-Undangan (selanjutnya disebut Permenkumham No. 23 Tahun 2018).

Permenkumham Nomor 23 Tahun 2018 diundangkan pada tanggal 23 Agustus 2018 dan

ed. Wishnu Basuki, ke 2. (Jakarta: PT Tata Nusa, 2001). mulai berlaku sejak tanggal 23 September 2018, yang bertujuan untuk mengharmonisasikan proses penyelarasan substansi rancangan peraturan perundang-undangan dan teknik penyusunan peraturan perundang-undangan, baik Rancangan Peraturan Menteri, Rancangan Peraturan Lembaga Pemerintah Nonkementerian, dan Rancangan Peraturan dari Lembaga Nonstruktural oleh perancang peraturan perundang-undangan. Pembentukan Permenkumham Nomor 23 Tahun 2018 didasarkan pada Bab III tentang Jenis, Hierarki, Dan Materi Muatan Peraturan Perundang-Undangan Pasal 7 dan Pasal 8 Undang-Undang 12 Tahun 2011 tentang Pembentukan Peraturan Perundang-Undangan serta Pasal 3 ayat (1) dan (2) Peraturan Pemerintah Nomor 59 Tahun 2015 tentang Keikutsertaan Perancang Peraturan Perundang-Undangan dalam Pembentukan Peraturan Perundang-Undangan dan Pembinaannya.

Pasal 3 ayat (1) dan (2) secara eksplisit menjelaskan bahwa perancang memiliki tugas menyiapkan, merumuskan dan mengolah rancangan peraturan perundang-undangan dan instrumen hukum lainnya dan dalam pelaksanaan hal tersebut perancang peraturan perundangundangan harus melakukan pengharmonisasian, serta harus melampirkan surat selesai harmonisasi. Namun demikian, diundangkannya Permenkumham No. 23 Tahun 2018 telah menuai pro dan kontra. Salah satu kontranya, Kementerian Dalam Negeri telah mengajukan keberatan kepada Menteri Hukum dan HAM melalui surat Menteri Dalam Negeri Nomor 180/7182/SJ tertanggal 19 September 2018. Isi surat tersebut tersirat bahwa Kementerian Dalam Negeri meminta untuk mencabut Permenkumham Nomor 23 Tahun 2018 terkait pengharmonisasian peraturan menteri dan lembaga pemerintah nonkementerian, hal ini dikarenakan telah melampaui kewenangan dan bertentangan dengan peraturan perundangundangan yang lebih tinggi.

Pernyataan di atas didukung dengan fakta berupa pengajuan Judicial Review ke Mahkamah Agung yang diajukan secara perorangan dengan surat permohonan Nomor: 71/Per-PSG/XI/71 P/HUM/ 2018. ${ }^{3}$ Berdasarkan fakta tersebut, dapat diasumsikan bahwa Permenkumham Nomor 23

\footnotetext{
Mahkamah Agung RI, Putusan MAHKAMAH AGUNG Nomor 71 P/HUM/2018 Tahun 2018, 2018.
} 
tahun 2018 tersebut tidak sesuai dengan peraturan perundang-undangan yang lebih tinggi, antara lain : (i) Undang-Undang Nomor 12 Tahun 2011 tentang Pembentukan Peraturan Perundang-undangan; (ii) Peraturan Presiden No. 87 Tahun 2014 Tentang Peraturan Pelaksanaan Undang-Undang Nomor 12 Tahun 2011 tentang Pembentukan Peraturan Perundang-undangan; dan (iii) Peraturan Pemerintah No. 59 Tahun 2015 tentang keikut sertaan Perancang Peraturan Perundang-undangan dalam Pembentukan Peraturan Perundangundangan dan Pembinaannya.

Rumusan masalah yang diangkat dalam penelitian ini adalah (i) apakah pembentukan Permenkumham Nomor 23 Tahun 2018 telah sesuai dengan peraturan perundang-undangan; dan (ii) bagaimana efektivitas pelaksanaan Permenkumham Nomor 23 Tahun 2018? Sedangkan untuk tujuan dari penelitian ini adalah (i) Untuk mengetahui keabsahan dan menganalisis proses pembentukan Permenkumham Nomor 23 Tahun 2018; dan (ii) untuk mengetahui efektivitas dan menganalisis pelaksanaan Permenkumham Nomor 23 Tahun 2018 terkait pengharmonisasian peraturan rancangan kementerian dan lembaga oleh perancang peraturan perundang-undangan.

\section{METODE PENELITIAN}

Penelitian ini merupakan penelitian hukum yuridis normatif yang bersifat desktiptif analitis, ${ }^{4}$ dimana penelitian ini menggambarkan secara keseluruhan obyek yang diteliti secara sistematis dengan menganalisis data-data yang diperoleh. Adapun lokasi penelitian ini berada di Daerah Khusus Ibukota Jakarta dengan sejumlah $32 \mathrm{~K} / \mathrm{L}$ yang terdiri dari 18 Kementerian dan 14 Lembaga sebagai informan yang merupakan pemangku kepentingan dalam proses pengharmonisasian Rancangan Peraturan Menteri/Lembaga. Pemilihan informan ini didasarkan pada pertimbangan karakteristik K/L, sebagai berikut:

1. Kewenangan yang diberikan oleh peraturan perundang-undangan. Setiap $\mathrm{K} / \mathrm{L}$ memiliki kewenangan yang berbeda-beda dalam proses pembentukan, kewenangan, tugas dan fungsinya. Ada lembaga-lembaga yang memiliki kewenangan berdasarkan UUD 1945 dan UU.

4 Soeyono Soekanto, Pengantar Penelitian Hukum (Jakarta: Universitas Indonesia Press, 1982).
2. Dinamika dalam pembentukan peraturan perundang-undangan. Setiap $\mathrm{K} / \mathrm{L}$ memiliki dinamika yang berbeda-beda dalam menerbitkan peraturan perundang-undangan.

3. Independensi. Beberapa lembaga negara memiliki kewenangan yang independen dan tidak tersubordinasi dalam struktur pemerintahan secara umum.

4. Sumber Daya Manusia. Tidak setiap K/L memiliki perancang peraturan perundang-undangan. Data yang diperoleh dari Direktorat Jenderal Peraturan Perundang-Undangan Kementerian Hukum dan Hak Asasi Manusia Per-tanggal 28 Februari 2019 menyebutkan bahwa jumlah perancang di Direktorat Jenderal PP sejumlah 99 orang, 77 orang pada Kementerian dan 62 orang pada Lembaga Pemerintah Nonkementerian.

\section{PEMBAHASAN DAN ANALISIS}

\section{A. Keberadaan Undang-Undang Dalam Suatu Negara}

Keberadaan undang-undang dalam suatu negara modern sangat dipengaruhi oleh paham hukum positivisme, yang memandang hakikat hukum tidak lain dari pada norma-norma positif dalam sistem perundang-undangan. ${ }^{5}$ Menurut Soetandyo Wignjosoebroto, doktrin positivisme mengajarkan hukum itu harus memiliki sosok yang tidak berada di ranah yang meta yuridis, melainkan di ranah yang "menampak dan terbaca tegas dan jelas" dengan sifatnya yang objektif. Oleh sebab itu, setiap norma yang terbilang hukum harus dirumuskan (karena itu juga harus tertulis) secara eksplisit, cermat dan tepat oleh pejabat dan/atau institusi yang berkewenangan untuk itu. Berdasarkan doktrin positivisme inilah asal muasal pendapat setiap hukum (ius) itu harus diwujudkan dalam bentuk undang-undang (lege, lex). ${ }^{6}$

Menurut Satjipto Rahardjo, mengemukakan undang-undang dapat dilihat sebagai dokumen yang menuntun proses dan perilaku dalam masyarakat. Banyak lembaga atau kekuatan lain di

5 Anthon F.Susanto, Butir-Butir Pemikiran Dalam Hukum (Bandung: Refika Aditama, 2008).

6 Soetandyo Wignjosoebroto, "Menggagas Terwujudnya Peradilan Yang Independen Dengan Hakim Profesional Yang Tidak Memihak," Komisi Yudisial Vol I/No 3 (Jakarta, 2006). 
masyarakat yang sebenarnya juga berfungsi memberikan tuntunan seperti itu. Ada adat, kebiasaan, dan berbagai norma hukum lainnya. Dalam konteks dan tradisi negara dan hukum modern, undang-undang memiliki kelebihan di atas norma yang lain itu. Kelebihan itu disebut legalitas dan legitimasi yang biasanya hanya diberikan kepada undang-undang sebagai dokumen yang dihasilkan oleh kekuasaan legislatif, sebagai satusatunya badan dalam negara modern yang diberi wewenang untuk membuat hukum. ${ }^{7}$

Menurut Hans Kelsen, undang-undang adalah norma umum yang diciptakan dengan proses legislasi yang tingkat struktur hierarkinya di bawah konstitusi. Norma umum ini diaplikasikan oleh organ yang kompeten, khususnya pengadilan dan otoritas administratif. Norma hukum umum undang-undang memiliki dua fungsi besar, yaitu: (i) menentukan organ pelaksana hukum dan prosedur yang harus diikuti; dan (ii) menentukan tindakan yudisial dan administratif organ tersebut. Sehingga tindakan inilah yang menciptakan norma individual, yaitu penetapan norma hukum pada kasus nyata. ${ }^{8}$

Kemudian ditegaskan oleh A. Hamid S. Attamimi dengan mengutip I.C. van der Vlies. Terdapat dua pendapat mengenai pengertian pembentukan wet (undang-undang). Pendapat pertama, mengatakan pembentukan wet sebagaimana dimaksud dalam Grondwet (konstitusi/UUD negeri Belanda) adalah pelaksanaan suatu tugas tertentu. Pendapat ini ditentang oleh pendapat lain yang menganggap, apa yang dimaksud dalam UUD dengan pembentukan undang-undang adalah tidak lain dari penjabaran prosedur yang harus diikuti dalam membuat suatu undang-undang.

Hal terakhir ini melihat ketentuan pembentukan undang-undang dalam UUD tidak lebih dari prosedur formal pembuatan suatu undang-undang, tanpa memperdulikan apa yang diatur (materi) dalam undang-undang tersebut. Pendapat ini disebut pemahaman tentang undangundang yang formal (het formele wetsbegrib). Sebaliknya, pendapat yang pertama yang menganut pemahaman tentang undang-undang yang material menganggap, kepada pembentuk undang-undang

7 Satjipto Rahardjo, Membedah Hukum Progesif (Jakarta: Kompas, 2008).

8 Jimly Asshiddiqie and Ali Safaat, Teori Ham Kelsen Tentang Hukum (Jakarta: Konstitusi Press, 2006). dibebankan tugas tertentu sehingga pengertian tentang apa yang dimaksud dengan undangundang ialah suatu peraturan yang mengandung isi atau materi tertentu, dan karena itu diperlukan prosedur pembentukan yang tertentu pula (het materiele wetsbegrib). ${ }^{9}$

Mengenai pemahaman tentang undangundang yang formal (het formele wetsbegrib) menurut I.C. van der Vlies cocok sekali dengan penafsiran limitatif dan penafsiran enunsiatif. Penafsiran limitatif adalah jika UUD memberikan rincian limitatif yang tegas mengenai tugas-tugas/materi tertentu yang harus dibuat dalam bentuk undang-undang oleh pembuat undangundang. Jika UUD telah memasukkan pembagian tugas-tugas secara rinci, maka penafsiran limitatif berpandangan pembuat undang-undang tidak boleh mengatur di luar tugas-tugas yang dirinci. Konsekuensi dari paham UUD memuat suatu penetapan tugas secara limitatif bagi pembuat undang-undang adalah ada suatu organ lain, misalnya pemerintah yang harus melaksanakan tugas-tugas yang tidak disebut itu. Paham tugastugas pembuat undang-undang harus dituangkan secara limitatif, cocok dengan paham dari mereka yang berpendapat tugas-tugas yang tak terbagi itu masuk ke dalam urusan pemerintah. ${ }^{10}$

Menurut penafsiran enunsiatif (dalam arti tidak menutup kemungkinan untuk mengatur bentuk-bentuk lain sesuai dengan kebutuhan) jika UUD tidak memasukkan rincian yang limitatif tetapi yang enunsiatif, maka pembuat undangundang boleh mengatur tugas-tugas lain lagi. Menurut paham ini, dalam hal perincian tugas pembuat undang-undang dalam UUD itu bersifat enunsiatif, maka suatu subjek yang baru dapat diatur oleh pembuat undang-undang, pemerintah maupun seorang menteri. ${ }^{11}$

9 A Hamid S. Attamimi, "Teori Perundang-Undangan Indonesia, Suatu Sisi Ilmu Pengetahuan PerundangUndangan Indonesia Yang Menjelaskan Dan Menjernihkan Pemahaman," in Pidato Pada Upacara Pengukuhan Jabatan Guru Besar Tetap Pada Fakultas Hukum Universitas Indonesia (Jakarta, 1992).

10 I. C. van der Vlies, Buku Pegangan Perancang Peraturan Perundang-Undangan (Handboek Wetgeving), ed. Linus Doludjawa (Jakarta: Dirjen PP Depkumham, 2005).

11 Bayu Dwi Anggono, Perkembangan Pembentukan Undang-Undang Di Indonesia, cet. 1 ed (Jakarta: Konstitusi Press, 2014) at 19. 
Untuk sederhananya, orang dapat mengatakan perkara-perkara serupa boleh diatur secara bebas oleh salah satu dari organ tadi. Penganut paham ini berpendapat, pembuat UUD kenyataannya tidak membagi-bagikan subjeksubjek itu, dan juga tidak memuat kriteria umum yang dapat dipakai untuk melimpahkan subjeksubjek yang tak terbagi kepada suatu organ tertentu, selain itu UUD tidak memuat sanksi bagi pengaturan oleh organ yang tidak berwenang, seandainya pun timbul perbedaan pendapat mengenai soal kewenangan. Tanpa memandang organ mana yang telah membuat suatu peraturan, peraturan tersebut tetap berlaku. Jadi masalah tunjangan sosial boleh, menurut paham ini, diatur oleh pembuat undang-undang, oleh pemerintah, atau oleh seorang menteri. ${ }^{12}$

Penafsiran limitatif cocok dengan pemahaman undang-undang yang formal (het formele wetsbegrib) karena keduanya saling mengisi. Di dalam UUD tugas-tugas dirinci secara limitatif dan di dalam UUD ditentukan bagaimana tugas-tugas itu harus dilaksanakan. Penafsiran enunsiatif cocok dengan paham tentang undangundang yang formal (het formele wetsbegrib), karena pilihan mengenai apa yang di samping tugas-tugas dari UUD itu harus diatur oleh undangundang, diserahkan kepada pembuat undangundang selama pembuat undang-undang melakukannya sesuai dengan prosedur yang ditetapkan dalam UUD.

Pemahaman tentang undang-undang yang material (het materiele wetsbegrib) cocok dengan penafsiran yang disebut oleh De Bosch Kemper sebagai penafsiran ketiga (karena di luar penafsiran limitatif dan penafsiran enunsiatif). Penafsiran ketiga ini bertolak dari asumsi tugas pembuat undang-undang dirinci di dalam UUD secara enunsiatif. Namun, menurut paham ini, rincian ini tidaklah semaunya dan tidak boleh ditambah semaunya. Untuk dapat melaksanakan sendiri subjek-subjek yang tidak disebut dalam UUD, orang harus menyelidiki dulu apa yang telah menggerakkan pembuat UUD ketika menyerahkan atau tidak menyerahkan pengaturan atas subjek tertentu kepada pembuat undang-undang.

Sejalan dengan pendapat di atas, A Hamid S. Attamimi menegaskan pandangannya bahwa perlunya untuk mengetahui pemahaman tentang undang-undang Indonesia sebagaimana

12 Ibid. dikehendaki oleh UUD 1945, apakah UUD 1945 menganut pemahaman yang formal ataukah yang material (formeel atau materiel wetsbegrip). Hal itu mengingat banyak pihak yang masih belum memperoleh kejelasan apakah segala sesuatu atau setiap hal/pokok (onderwerp subject) dapat dituangkan dalam undang-undang (formeel wets begrip) ataukah hanya hal-hal atau pokok-pokok tertentu saja (materiel wets begrip). Dengan melihat dan melakukan analisis pada UUD 1945 A. Hamid S. Attamimi berpendapat UUD 1945 menganut pemahaman tentang undang-undang yang material. ${ }^{13}$

Menurut A. Hamid S. Attamimi ketentuan dalam UUD 1945 bukanlah hanya menunjuk bagaimana prosedur pembentukan suatu undangundang, yaitu dilakukan Presiden dengan persetujuan DPR. Melainkan, apabila dikaitkan dengan pendapat Buijs sebagai penganut paham tentang undang-undang material yang menyatakan penafsiran lebih baru menyangkut membuat undang-undang adalah penafsiran yang menyatakan keputusan yang bersifat mendalam harus diatur dengan undang-undang. Dalam pembentukan undang-undang di Indonesia meskipun kekuasaan membentuk di tangan Presiden namun untuk dapat terbentuk undangundang menghendaki persetujuan DPR, dapat diartikan keputusan yang diambil tentunya bersifat mendalam karena pengambilan keputusan tersebut memerlukan persetujuan 2 (dua) lembaga yaitu Presiden dan DPR.

Bagaimana dengan pemahaman tentang undang-undang setelah dilakukannya perubahan UUD 1945?. Untuk menjawab hal tersebut Maria Farida Indrati S, melakukan analisis terhadap ketentuan pembentukan undang-undang dalam UUD 1945 setelah perubahan yang mengatur: (i) Presiden berhak mengajukan Rancangan UndangUndang kepada Dewan Perwakilan Rakyat; (ii) Dewan Perwakilan Rakyat memegang kekuasaan membentuk Undang-Undang; dan (iii) Setiap Rancangan Undang-Undang dibahas oleh Dewan Perwakilan Rakyat dan Presiden untuk mendapat persetujuan bersama. ${ }^{14}$

13 A. Hamid S. Attamimi, 1990, Peranan Keputusan Presiden Republik Indonesia dalam Penyelenggaraan Pemerintahan Negara, [Disertasi], Universitas Indonesia.

14 Maria Farida Indrawati, Ilmu PerundangUndangan, Jenis, Fungsi, Dan Materi Muatan (Jakarta: Kanisius, 2007). 
Apabila membaca perumusan UUD 1945 setelah perubahan dapat ditafsirkan meskipun Presiden hanya berhak untuk mengajukan Rancangan Undang-Undang usul inisiatif kepada DPR, namun di dalam membentuk undang-undang DPR harus melaksanakannya dengan persetujuan, atau dengan berbarengan, serentak, bersama-sama dengan Presiden. Agar undang-undang itu dapat terbentuk, kedua kewenangan tersebut dilaksanakan bersama-sama, oleh DPR dan Presiden.

Pendapat tersebut sejalan dengan pandangan Saldi Isra, frasa "persetujuan bersama" yang terdapat dalam UUD 1945 memberikan otoritas ganda dalam pembentukan undang-undang. Otoritas ganda tersebut memunculkan tiga hal pokok, yaitu: (i) tidak akan pernah ada undangundang tanpa persetujuan bersama antara Presiden dan DPR; (ii) jika salah satu pihak (Presiden dan DPR) tidak menyetujui, maka rancangan undangundang tersebut tidak dibolehkan lagi diajukan dalam masa persidangan DPR saat itu; dan (iii) kewenangan persetujuan rancangan undang-undang menjadi undang-undang merupakan otoritas bersama antara DPR dan Presiden. ${ }^{15}$

Berdasarkan uraian tersebut, terlihat setelah perubahan UUD 1945 pemahaman tentang undangundang tersebut tetap menganut pemahaman tentang undang-undang yang material karena bukan sekadar prosedur formal yang diinginkan, melainkan undang-undang tersebut adalah suatu peraturan yang mengandung isi atau materi tertentu yang karena sifatnya mendalam sehingga memerlukan persetujuan bersama antara DPR dengan Presiden. Dengan menganut pemahaman tentang undang-undang yang material, maka tugas pembuat undang-undang selain membuat peraturanperaturan mengenai hal-hal yang di dalam UUD telah ditetapkan harus diatur dengan atau berdasarkan undang-undang, dimungkinkan ada hal-hal tertentu di luar yang telah ditetapkan dalam UUD tersebut untuk diatur dengan undang-undang. Namun demikian, hal-hal di luar yang telah ditetapkan dalam UUD tersebut tidaklah boleh semaunya dan, karenanya, tidak boleh ditambahtambah semaunya melainkan harus ditentukan ruang lingkupnya.

Pada dasarnya dalam pembentukan suatu

15 Saldi Isra, Pergeseran Fungsi Legislasi, Menguatnya Model Legislasi Parlementer Dalam Sistem Presidensial Indonesia (Jakarta: Rajawali Pers, 2010). peraturan perundang-undangan, peraturan tersebut tidak boleh bertentangan dengan peraturan yang lebih tinggi dan tertinggi. Sementara itu Hans Kelsen menegaskan bahwa hukum yang tertinggi dalam suatu negara adalah norma dasar (groundnorm). Kelsen menambahkan bahwa keabsahan dari suatu norma hukum sangat bergantung pada apakah norma hukum tersebut bertentangan dengan norma hukum dasar sebagai norma tertinggi dan norma hukum lainnya sebagai norma yang lebih tinggi. Kemudian Kelsen membagi norma-norma sebagai, yakni sebagai berikut:

1. Norma dasar negara (staatsfundamentalnorm) yang dalam kerangka hukum NKRI dapat diartikan sebagai Pancasila;

2. Aturan dasar konstitusi (staatsgroundgeset) yang dalam kerangka hukum NKRI diartikan sebagai UUD 1945;

3. Undang-undang formil (formelgeset);

4. Peraturan pelaksana (verordnungen automene satzung). ${ }^{16}$

Oleh karena itu, pengertian dari peraturan perundang-undangan ditentukan dalam Pasal 1 angka 2 Undang-Undang Nomor 12 Tahun 2011 tentang Pembentukan Peraturan Perundangundangan yaitu peraturan tertulis yang memuat norma hukum yang mengikat secara umum dan dibentuk atau ditetapkan oleh lembaga negara atau pejabat yang berwenang melalui prosedur yang ditetapkan dalam Peraturan Perundang-undangan. Dalam penelitian ini yang diteliti adalah pentingnya harmonisasi peraturan perundangundangan.

Pasal 7 Undang-Undang Nomor 12 Tahun 2011 mengatur mengenai hierarki peraturan perundang-undangan sebagai berikut:

(1) Jenis dan hierarki peraturan perundangundangan terdiri atas:

a. UUD 1945;

b.Ketetapan Majelis Permusyawaratan Rakyat ;

c. Undang-Undang/PeraturanPemerintah

Pengganti Undang-Undang;

d.Peraturan Pemerintah;

16 Indrawati, Ilmu Perundang-Undangan, Jenis, Fungsi, Dan Materi Muatan. 


\section{e. Peraturan Presiden;}

\section{f. Peraturan Daerah Provinsi; dan \\ g.Peraturan Daerah Kabupaten/Kota.}

(2) Kekuatan hukum peraturan perundangundangan sesuai dengan hierarki sebagaimana dimaksud pada ayat (1).Pengertian peraturan perundang-undangan adalah:

a. Setiap keputusan tertulis yang dikeluarkan pejabat atau lingkungan jabatan yang berwenang yang berisi aturan tingkah laku yang bersifat atau mengikat umum.

b. Merupakan aturan-aturan tingkah laku yang berisi ketentuan-ketentuan mengenai hak kewajiban, fungsi, dan status atau suatu tatanan.

c. Peraturan yang mempunyai ciri-ciri umumabstrak atau abstrak-umum, artinya tidak mengatur atau tidak ditujukan pada obyek, peristiwa atau gejala konkret tertentu.

d. Dengan mengambil pemahaman dalam kepustakaan Belanda, peraturan perundangundangan lazim disebut dengan wet in materiële zin atau sering juga disebut dengan algemeen verbindende voorschrift.

Jadi unsur-unsur peraturan perundangundangan adalah suatu peraturan yang bersifat umum-abstrak, tertulis, mengikat umum, dibentuk oleh lembaga atau pejabat yang berwenang dan bersifat mengatur. Nomenklatur "perundangundangan" dapat didahului dengan kata lain, misalnya peraturan, sehingga menjadi "peraturan perundang-undangan". ${ }^{17}$

Nomenklatur peraturan adalah aturan-aturan yang dibuat oleh yang berkuasa untuk mengatur sesuatu, yang dibuat oleh pemerintah, yang salah satu bentuknya adalah undang-undang. Nomenklatur "aturan" dalam bahasa Arab disebut sebagai "kaidah" dan dalam bahasa Latin disebut dengan "norma". Nomenklatur "peraturan perundang-undangan mempunyai arti yang lebih fokus yakni aturan (kaidah, norma) yang dibuat oleh yang berkuasa melalui prosedur yang ditetapkan dalam peraturan perundang-undangan untuk mengatur sesuatu. Peraturan perundangundangan bersifat umum, abstrak dan terus

17 Rachma Trijono, Dasar-Dasar Ilmu Pengetahuan Perundang-Undangan (Depok: Papas Sinar Sinanti, 2013). menerus. Hal ini berbeda dengan keputusan yang bersifat konkret, individual, dan final. Selanjutnya bahwa unsur-unsur peraturan perundangundangan terdiri atas:

a. Peraturan tertulis;

b. Dibentuk oleh lembaga negara atau pejabat Negara;

c. Melalui prosedur yang ditetapkan dalam peraturan perundang-undangan; dan

d. Mengikat secara umum.

Peraturan perundang-undangan merupakan bentuk formal dari hukum. Peraturan perundangundangan memuat sekumpulan norma hukum yang dikukuhkan/ditetapkan oleh negara yang berlaku umum untuk masyarakat. Sebagai aturan formal, tentu peraturan perundang-undangan dalam penyusunannya haruslah memperhatikan berbagai asas sehingga peraturan perundangundangan tersebut dapat berlaku efektif setelah ditetapkan. Baik efektivitas karena adanya sanksi yang diberlakukan (positivism), maupun karena kesadaran yang muncul (sociological).

Sebagaimana yang telah dikemukan bahwa sesungguhnya asas pembentukan peraturan perundang-undangan (Beginselen Van Behoorlijke Regelgeving) banyak dikembangkan oleh para sarjana hukum. Salah satunya adalah asas yang dikembangkan oleh IC Van der Vlies. Menurutnya pembentukan peraturan perundang-undangan yang baik (Beginselen Van Behoorlijke Regelgeving) haruslah memperhatikan asas-asas sebagai berikut:

1. Asas Formal

a. Asas tujuan yang jelas (Beginsel van Duidelijke Doelstelling);

b. Asas organ/lembaga yang tepat (Beginsel van Het Juiste Orgaan);

c. Asas perlunya pengaturan (Het Noodzakelijkheids Beginsel);

d. Asas dapat dilaksanakan (Het Beginsel van Uitvoerbaarheid);

e. Asas konsensus (Het Beginsel van
Consensus).

2. Asas Materiil 
a. Asas terminologi dan sistematika yang benar (Het Beginsel van Duidelijk Terminologi En Duidelijke Systematiek);

b. Asas dapat dikenali (Het Beginsel van De Kenbaarheid);

c. Asas perlakukan hukum yang sama (Het Rechtsgelijkheids Beginsel);

d. Asas kepastian hukum Rechtszekerheids Beginsel);

(Het

e. Asas pelaksanaan hukum sesuai dengan keadaan individual (Het Beginsel van De Individuele Rechtsbedeling).

Dengan pemahaman asas-asas seperti tersebut di atas maka sesungguhnya telah termuat dalam Undang-Undang Nomor 12 Tahun 2011 tentang Pembentukan Peraturan Perundangundangan pada tujuh asas pembentukan peraturan perundang-undangan tersebut dapat dijelaskan sebagai berikut:

1. Asas Kejelasan

Tujuan Asas ini menyatakan bahwa setiap pembentukan peraturan perundang-undangan harus mempunyai tujuan yang jelas yang hendak dicapai.

2. Asas Kelembagaan atau Pejabat Pembentuk yang Tepat

Asas ini menyatakan bahwa setiap jenis peraturan perundang-undangan harus dibuat oleh lembaga negara atau pejabat pembentuk peraturan perundang-undangan yang berwenang. Peraturan perundang-undangan tersebut dapat dibatalkan atau batal demi hukum apabila dibuat oleh lembaga negara atau pejabat yang tidak berwenang.

3. Asas Kesesuaian antara Jenis, Hierarki, dan Materi Muatan

Asas ini menyatakan bahwa dalam pembentukan peraturan perundang-undangan harus benar-benar memperhatikan materi muatan yang tepat sesuai dengan jenis dan hierarki Peraturan Perundang-undangan.

4. Asas Dapat Dilaksanakan

Asas ini menyatakan bahwa setiap pembentukan peraturan perundang-undangan harus memperhitungkan efektivitas peraturan perundang-undangan tersebut di dalam masyarakat, baik secara filosofis, sosiologis, maupun yuridis.

5. Asas Kedayagunaan dan Kehasilgunaan

Asas ini menyatakan bahwa setiap peraturan perundang-undangan dibuat karena memang benar-benar dibutuhkan dan bermanfaat dalam mengatur kehidupan bermasyarakat, berbangsa, dan bernegara.

6. Asas Kejelasan Rumusan

Asas ini menyatakan bahwa setiap peraturan perundang-undangan harus memenuhi persyaratan teknis penyusunan peraturan perundang-undangan, sistematika, pilihan kata atau istilah, serta bahasa hukum yang jelas dan mudah dimengerti sehingga tidak menimbulkan berbagai macam interpretasi dalam pelaksanaannya.

\section{Asas Keterbukaan}

Asas ini menyatakan bahwa dalam pembentukan peraturan perundang-undangan mulai dari perencanaan, penyusunan, pembahasan, pengesahan atau penetapan, dan pengundangan bersifat transparan dan terbuka.

Berdasarkan Kamus Besar Bahasa Indonesia, kata harmonis diartikan sebagai sesuatu yang berkaitan dengan harmoni, atau seia-sekata, sedangkan kata harmonisasi diartikan sebagai pengharmonisan, atau upaya mencari keselarasan. ${ }^{18}$ Dalam penelitian ini kata harmonisasi juga digunakan sebagai upaya untuk mencari kesesuaian/keselarasan antara peraturan perundang-undangan agar tidak terjadi duplikasi pengaturan.

Secara etimologi, kata efektivitas berasal dari kata efektif sebagai terjemahan dari kata effective dalam bahasa Inggris yang dalam bahasa Indonesia memiliki makna berhasil, dan dalam bahasa Belanda dikenal kata effectief yang memiliki makna berhasil guna. Secara umum, kata efektivitas menunjukkan keberhasilan dari segi tercapai tidaknya sasaran yang telah ditetapkan. Jika hasilnya semakin mendekati sasaran, berarti makin tinggi efektivitas. ${ }^{19}$ Dalam konteks hukum, maka efektivitas hukum secara tata bahasa dapat

18 Kementerian Pendidikan dan Kebudayaan, Kamus Besar Bahasa Indonesia, 4th ed. (Jakarta: PT Gramedia Pustaka Utama, 2013).

19 Sondang P. Siagian, Kiat Meningkatkan Produktifitas Kerja (Jakarta: Rhineka Cipta, 2002). 
diartikan sebagai keberhasilgunaan hukum, yaitu keberhasilan dalam meng-implementasikan hukum itu sendiri dalam tatanan masyarakat. ${ }^{20}$

Peraturan Perundang-undangan adalah peraturan tertulis yang dibentuk oleh lembaga negara atau pejabat yang berwenang dan mengikat secara umum. Berdasarkan pengertian tersebut, maka peraturan perundang-undangan bersifat umum-abstrak, yang dicirikan unsur-unsur antara lain (i) waktu, artinya tidak hanya berlaku pada saat tertentu saja, (ii) tempat, artinya tidak hanya berlaku pada tempat tertentu saja, (iii) orang, artinya tidak hanya berlaku bagi orang tertentu saja, dan (iv) fakta hukum, artinya tidak hanya ditujukan pada fakta hukum tertentu saja, tetapi untuk berbagai fakta hukum (perbuatan) yang dapat berulang-ulang. ${ }^{21}$

Perancang peraturan perundang-undangan yang selanjutnya disebut Perancang adalah Aparatur Sipil Negara baik di dalam dan/atau di luar Kementerian Hukum dan Hak Asasi Manusia yang telah diangkat dalam jabatan fungsional Perancang yang diberi tugas, tanggung jawab, wewenang, dan hak secara penuh oleh pejabat yang berwenang atau instansi Pembina perancang untuk melakukan kegiatan pembentukan peraturan perundang-undangan dan penyusunan instrumen hukum lainnya.

Pengharmonisasian rancangan peraturan perundang-undangan yang selanjutnya disebut Pengharmonisasian adalah proses penyelarasan substansi rancangan peraturan perundang-undangan dan teknik penyusunan peraturan perundangundangan, sehingga menjadi peraturan perundangundangan yang merupakan satu kesatuan yang utuh dalam kerangka sistem hukum nasional. ${ }^{22}$

Selain itu, fungsi dari harmonisasi peraturan perundang-undangan juga sebagai tindakan preventif guna mencegah terjadinya Judicial Review suatu peraturan perundang-undangan karena jika hal ini terjadi maka akan timbul berbagai macam kerugian baik dari segi biaya, waktu, maupun tenaga. Dari segi biaya peraturan perundang-undangan tersebut dalam

20 Soerjono Soekanto, Sosiologi: Suatu Pengantar (Bandung: Rajawali Press, 1996).

21 Wicipto Setiadi, "Continuing Legal Eduacation (CLE): Instrumen Pemerintahan" (Jakarta: Pusat Penelitian dan Pengembangan Sistem Hukum Nasional, BPHN, 2011).

22 Lihat Pasal 1 angka 2 UU 12 Tahun 2011 penyusunannya dibiayai dari dana APBN yang tidak sedikit, dari segi waktu proses penyusunannya membutuhkan waktu yang tidak sebentar bahkan dapat memakan waktu bertahuntahun, sedangkan dari segi tenaga dalam penyusunan peraturan perundang-undangan dibutuhkan banyak energi, konsentrasi, dan koordinasi dari pembuat peraturan perundangundangan tersebut. Dengan adanya proses harmonisasi peraturan perundang-undangan yang baik maka potensi berbagai kerugian di atas dapat dicegah. ${ }^{23}$

\section{B. Keabsahan Permenkumham No. 23 Tahun 2018}

Dalam menjawab

keabsahan Permenkumham No. 23 Tahun 2018 berdasarkan metode yuridis normatif, penelitian ini merujuk pada Undang-undang No. 12 Tahun 2011 tentang Pembentukan Peraturan Perundang-undangan yang mengatur hierarki peraturan perundangundangan sebagai berikut: (a) Undang-Undang Dasar 1945, (b) Ketetapan Majelis Permusyawaratan Rakyat, (c) Undangundang/peraturan pemerintah pengganti undangundang, (d) Peraturan Pemerintah, (e) Peraturan Presiden; (f) Peraturan Daerah, meliputi; Peraturan Daerah Provinsi, Peraturan Daerah Kabupaten/Kota dan Peraturan Desa atau yang setingkat.

Selain yang diatur sesuai hierarki peraturan perundang-undangan, terdapat kedudukan peraturan perundang-undangan lain di luar yang disebutkan dalam hierarki Pembentukan Peraturan Perundang-undangan yang diatur dalam pasal 8 UU No.12 Tahun 2011, memberikan ketegasan bahwa: jenis peraturan perundang-undangan selain dimaksud dalam Pasal 7 ayat (1), tetap diakui keberadaannya dan mempunyai kekuatan hukum mengikat sepanjang diperintahkan oleh peraturan perundang-undangan yang lebih tinggi.

Sedangkan yang dimaksud dengan kekuatan hukum peraturan perundang-undangan sesuai dengan "hierarki" peraturan perundang-undangan adalah penjenjangan setiap jenis peraturan

23 Setio Sapto Nugroho, Harmonisasi Pembentukan Peraturan Perundang-Undangan, Dokumentasi Dan Informasi Hukum, Bagian Hukum, Biro Hukum Dan Humas, Bidang Perekonomian Sekretariat Negara (Jakarta, 2009), ??? 
perundang-undangan yang didasarkan pada asas bahwa peraturan perundang-undangan yang lebih rendah tidak boleh bertentangan dengan peraturan perundang-undangan yang lebih tinggi.

Adanya penjelasan tentang kedudukan hukum dari jenis-jenis peraturan perundangundangan di luar hierarki yang disebutkan dalam Pasal 7 UU No. 12 Tahun 2011 dilatarbelakangi oleh pemikiran mengenai praktik ketatanegaraan dan pemerintahan ditemui berbagai ketentuan yang bersifat regulatif, yang ditetapkan oleh badan/atau pejabat yang diberi kewenangan untuk itu. Harus dipahami bahwa keberadaan dan kekuatan mengikat dari jenis peraturan perundang-undangan di luar hierarki seperti disebutkan dalam pasal 7 ayat (1) adalah hanya sepanjang diperintahkan dan tunduk pada prinsip hierarki. Hal ini sesuai dengan teori hierarki perundang-undangan yang disampaikan Hans Kelsen dan Friedman, bahwa suatu peraturan yang lebih rendah tidak dapat membentuk aturan bila tidak diperintahkan oleh peraturan yang lebih tinggi.

Berkaitan dengan teori kewenangan dari I.C. van der Vlies, kewenangan didefinisikan sebagai kemampuan bertindak yang diberikan oleh undangundang yang berlaku untuk melakukan hubungan dan perbuatan hukum. Salah satu prinsip utama yang dijadikan dasar dalam setiap penyelenggaraan pemerintahan dan kenegaraan di setiap negara hukum adanya asas legalitas. Dengan kata lain, setiap penyelenggaraan pemerintahan dan kenegaraan harus memiliki kewenangan yang diterjemahkan sebagai suatu kemampuan untuk melakukan suatu tindakan-tindakan hukum tertentu yang didasarkan pada delegasi dan/atau atribusi yang diberikan oleh peraturan perundangundangan.

Pembangunan materi hukum (legal substance) atau peraturan perundang-undangan di Indonesia hingga kini terus berlangsung (never ending process) karena peraturan perundangundangan merupakan salah satu sendi utama dari sistem hukum nasional. Namun demikian masih ditemukan peraturan perundang-undangan yang bermasalah, baik karena substansi, proses dan prosedur, maupun aspek legal drafting-nya. Paling tidak ada tiga permasalahan utama dibidang ini, yaitu: (i) tumpang tindih dan inkonsistensi peraturan perundang-undangan; (ii) perumusan peraturan perundang-undangan yang kurang jelas; dan (iii) implementasi undang-undang terhambat peraturan pelaksanaannya. Permasalahan tersebut di atas, antara lain, disebabkan oleh proses pembentukan peraturan perundangundangan yang mengabaikan pentingnya pendala man materi muatan, koordinasi, sinkronisasi dan harmonisasi denganperaturan perundangundangan lain. Oleh karena itu salah satu prioritas yang harus dilakukan dalam rangka pembangunan hokum nasional adalah melakukan harmonisasi peraturan perundang-undangan. ${ }^{24}$

Harmonisasi harus dilakukan secara sistemik sejak dini yaitu sejak dilakukannya penyusunan naskah akademik (NA), penyusunan Program Legislasi Nasional (Prolegnas) sampai dengan penyusunan RUU, RPP dan Rancangan Perpres. Aspek perencanaan merupakan salah satu faktor penting, oleh karena itu, pembentukan peraturan perundang-undangan harus dimulai dari perencanaan. Disusun secara berencana, terpadu dan sistematis, serta didukung oleh cara dan metode yang tepat, dan standar yang mengikat semua lembaga yang berwenang membuat peraturan perundang-undangan.

Berdasarkan pada pembahasan di atas, dalam UU No. 12 Tahun 2011 tentang Pembentukan Peraturan Perundang-undangan, Peraturan Pemerintah No. 59 Tahun 2015 tentang Keikutsertaan Perancang Peraturan Perundangundangan dalam Pembentukan Peraturan Perundang-undangan dan Pembinaannya serta Peraturan Presiden No. 87 Tahun 2014 tentang Peraturan Pelaksanaan Undang-Undang No. 12 tahun 2011 tentang Pembentukan Peraturan Perundang-undangan, tidak ada satu pasal pun yang memberikan delegasi kepada Kementerian Hukum dan HAM untuk mengharmonisasi Rancangan Peraturan Menteri atau Lembaga.

\section{Efektivitas Pelaksanaan Permenkumham No. 23 Tahun 2018}

Mengenai efektivitas pelaksanaan, berdasarkan hasil penelitian melalui pendekatan empiris, terdapat dua hal utama yang menjadi fokus, sebagai berikut :

Pertama adalah mengenai rasio perancang baik di Kementerian Hukum dan HAM dan K/L lainnya. Mayoritas $\mathrm{K} / \mathrm{L}$ berpendapat bahwa mereka tidak memiliki sumber daya perancang

24 Soegiyono, "Pentingnya Harmonisasi Pembentukan Peraturan Perundang-Undangan," Kajian Kebijakan Dan Hukum Kedirgantaraan LAPAN (Jakarta, n.d.). 
yang cukup atau bahkan tidak memiliki sama sekali perancang dan sebagian lagi menyatakan mereka telah memiliki perancang dalam jumlah dan kualitas yang memadai.

Ketiadaan perancang di $\mathrm{K} / \mathrm{L}$ ini memiliki implikasi pada kualitas harmonisasi dan sinkronisasi Permen atau Peraturan Lembaga yang mereka buat. Sebagai hasilnya, keterlibatan perancang dari Kementerian Hukum dan HAM dalam proses harmonisasi rancangan Permen atau Peraturan Lembaga cukup membantu dalam proses penyusunan peraturan di setiap K/L.

Data yang dikeluarkan oleh Direktorat Jenderal Peraturan Perundang-Undangan tanggal 28 Februari 2019 menyebutkan bahwa jumlah perancang di Direktorat Jenderal PP sejumlah 99 orang, 77 orang pada Kementerian dan 62 orang pada Lembaga Pemerintah Nonkementerian.

\section{Tabel 1}

\section{Jumlah Perancang Peraturan Perundangan- Undangan}

\begin{tabular}{|c|l|c|c|c|c|c|c|c|}
\hline \multirow{2}{*}{$\begin{array}{c}\text { N } \\
\text { o. }\end{array}$} & $\begin{array}{l}\text { Data } \\
\text { Perancang } \\
\begin{array}{l}\text { Peraturan } \\
\text { Perundang- } \\
\text { Undangan }\end{array}\end{array}$ & L & P & $\begin{array}{c}\text { Perta } \\
\text { ma }\end{array}$ & $\begin{array}{c}\text { Mud } \\
\text { a }\end{array}$ & $\begin{array}{c}\text { Mad } \\
\text { ya }\end{array}$ & $\begin{array}{c}\text { Uta } \\
\text { ma }\end{array}$ & \\
\hline 1 & Ditjen PP \\
. & 53 & 46 & 25 & 32 & 14 & 1 & 99 \\
\hline 2 & $\begin{array}{l}\text { KanwilKe } \\
\text { menkumh } \\
\text { am }\end{array}$ & 332 & 231 & 361 & 164 & 38 & 0 & 563 \\
\hline 3 & $\begin{array}{l}\text { Kementeri } \\
\text { an }\end{array}$ & 39 & 38 & 51 & 18 & 7 & 1 & 77 \\
\hline 4 & $\begin{array}{l}\text { Lembaga } \\
\text { pemerinta } \\
\text { hNonkem } \\
\text { enterian }\end{array}$ & 42 & 20 & 13 & 18 & 29 & 2 & 62 \\
\hline 5 & $\begin{array}{l}\text { Pemerinta } \\
\text { h Daerah }\end{array}$ & 6 & 7 & 10 & 3 & 0 & 0 & 13 \\
\hline 6. & $\begin{array}{l}\text { Kemenku } \\
\text { mham } \\
\begin{array}{l}\text { Pusat di } \\
\text { LuarDitje } \\
\text { n PP }\end{array}\end{array}$ & 19 & 25 & 42 & 1 & 1 & 0 & 44 \\
\hline Sub Total & 491 & 367 & 529 & 236 & 89 & 4 & 858 \\
\hline
\end{tabular}

Sumber: Direktorat Jenderal PeraturanPerundang-Undangan, Kementerian Hukum dan HAM PeriodeTanggal 28 Februari 2019

Walaupun demikian, keterlibatan perancang Kementerian Hukum dan HAM dalam proses harmonisasi peraturan di setiap $\mathrm{K} / \mathrm{L}$ masih memiliki kelemahan yang menjadi hambatan teknis dalam proses harmonisasi. Hal ini karena rasio jumlah perancang di Kementerian Hukum dan HAM tidak berbanding lurus dengan banyaknya jumlah peraturan perundang-undangan yang harus diharmonisasi. Jumlah perancang yang tidak berbanding lurus dengan jumlah rancangan peraturan perundang-undangan yang harus diharmonisasi menjadi hambatan dan kendala teknis bagi para $\mathrm{K} / \mathrm{L}$ untuk meminta Kementerian Hukum dan HAM dalam mempercepat proses harmonisasi.

Sementara itu bagi K/L yang telah memiliki perancang berpendapat bahwa penguatan peran perancang di setiap $\mathrm{K} / \mathrm{L}$ menjadi kunci dari proses harmonisasi. $\mathrm{K} / \mathrm{L}$ berpendapat bahwa jika proses harmonisasi hanya dimonopoli oleh perancang Kementerian Hukum dan HAM, maka ada kesan Kementerian Hukum dan HAM menafikan jumlah dan kemampuan perancang di K/L lain. Lebih lanjut, K/L justru mengeluhkan sulitnya mereka untuk mengajukan pegawai-pegawainya mengikuti pendidikan penyusunan dan perancangan peraturan perundang-undangan dan juga proses perpindahan jabatan untuk menjadi perancang, padahal $\mathrm{K} / \mathrm{L}$ berpendapat bahwa penguatan peran perancang di setiap $\mathrm{K} / \mathrm{L}$ merupakan upaya penyelesaian masalah dalam proses harmonisasi.

Kedua, berkaitan dengan proses harmonisasi, sebagian besar $\mathrm{K} / \mathrm{L}$ berpendapat bahwa substansi Permenkumham No. 23 Tahun 2018 tidak dilengkapi dengan mekanisme yang jelas mengenai prosedur pengharmonisasian dan jangka waktu dari proses harmonisasi. Selain permasalahan tersebut, faktor utama yang menghambat proses harmonisasi adalah pengulangan dalam pembahasan substansi pada saat tahapan proses harmonisasi. Artinya, ketika sudah dilakukan pembahasan substansi pada proses harmonisasi di masing-masing $\mathrm{K} / \mathrm{L}$, maka pembahasan substansi dilakukan kembali pada proses harmonisasi dengan Kementerian Hukum dan HAM. K/L menghendaki proses harmonisasi yang dilakukan oleh Kementerian Hukum dan HAM tidak terpisahkan dengan proses pengundangannya. Penggabungan proses harmonisasi dan pengundangan akan memotong alur birokrasi.

Sebanyak 19 (sembilan belas) K/L menyatakan bahwa mereka mematuhi Permenkumham No. 23 Tahun 2018 dengan 
alasan khawatir atas konsekuensi, di antaranya adalah tidak diundangkannya rancangan peraturan yang diajukan kepada Direktorat Jenderal Peraturan Perundang-Undangan. Konsekuensi lainnya adalah karena adanya perintah dan instruksi dari pimpinan yang memerintahkan untuk melaksanakan ketentuan Permenkumham No. 23 Tahun 2018. Pada sisi lainnya, sejumlah 11 (sebelas) K/L menyatakan mengakui legitimasi bahwa Permenkumham No.23 Tahun 2018 tidak bertentangan dengan peraturan perundangundangan.

\section{Undang-Undang Merupakan Salah Satu Bagian Dari Sistem Hukum}

Undang-Undang merupakan salah satu bagian dari sistem hukum, oleh karenanya proses pembentukan undang-undang akan sangat dipegaruhi oleh sistem hukum yang dianut oleh negara tempat undang-undang itu dibentuk. Sehingga, untuk mengkaji pembentukan undangundang secara komprehensif, haruslah dimulai dengan mengkaji sistem itu sendiri. Lawrence M. Friedman mengemukakan, untuk memahami sisstem hukum dapat dilihat dari unsur yang melekat pada sistem hukum itu sendiri, yaitu "Sistem hukum mempunyai unsur-unsur yaitu struktur hukum (legal structure), substansi hukum (legal substance), dan budaya hukum (legal culture)". Lebih lanjut dikemukakan bahwa untuk memudahkan pemahaman tentang sistem hukum, dapat dilakukan dengan:

“... menggambarkan ketiga unsur sistem hukum itu adalah dengan mengibaratkan struktur hukum seperti mesin. Substansi adalah apa yang dihasilkan atau dikerjakan oleh mesin. Budaya hukum adalah apa saja atau siapa saja yang memutuskan untuk meghidupkan dan mematikan mesinitu serta memutuskan bagaimana mesin itu digunakan. Satu saja komponen pendukung tidak berfungsi niscaya system mengalami kepincangan (disfunction)".

Dengan demikian dalam pembentukan peraturan perundang-undangan dikenal beberapa prinsip yang harus diperhatikan. Prinsip-prinsip tersebut adalah (i) tingkatan hirarki; (ii) landasan/dasar peraturan perundang-undangan selalu peraturan perundang-undangan; (iii) hanya peraturan perundang-undangan tertentu saja yang dapat dijadikan landasan/dasar yuridis; (iv) peraturan perundang-undangan baru menyampingkan peraturan perundang-undangan lama; dan (v) peraturan perundang-undangan yang bersifat khusus menyampingkan peraturan perundang-undangan yang bersifat umum.

Dalam menjawab keabsahan Permenkumham No. 23 Tahun 2018, penelitian ini merujuk pada Undang-undang Nomor 12 Tahun 2011 tentang Pembentukan Peraturan Perundangundangan mengatur hierarki peraturan perundangundangan sebagai berikut: (a) Undang-Undang Dasar 1945, (b) Ketetapan Majelis Permusyawaratan Rakyat, (c) Undangundang/peraturan pemerintah pengganti undangundang, (d) Peraturan Pemerintah, (e) Peraturan Presiden; (f) Peraturan Daerah, meliputi; Peraturan Daerah Provinsi, Peraturan Daerah Kabupaten/Kota dan Peraturan Desa atau yang setingkat.

Berkaitan dengan Pasal 8 Undang-Undang Nomor 12 Tahun 2011, kedudukan peraturan perundang-undangan lain di luar yang disebutkan dalam hierarki Pembentukan Peraturan Perundang-Undangan, memberikan ketegasan bahwa: jenis peraturan perundang-undangan selain dimaksud dalam Pasal 7 ayat (1), tetap diakui keberadaannya dan mempunyai kekuatan hukum mengikat sepanjang diperintahkan oleh peraturan perundang-undangan yang lebih tinggi.

Dalam ketentuan Pasal 8 UU No. 12 Tahun 2011, disebutkan bahwa jenis peraturan perundang-undangan yang diakui keberadaan dan mempunyai kekuatan hukum mengikat. Sedangkan yang dimaksud dengan kekuatan hukum peraturan perundang-undangan sesuai dengan "hierarki" peraturan perundang-undangan adalah penjenjangan setiap jenis peraturan perundang-undangan yang didasarkan pada asas bahwa peraturan perundang-undangan yang lebih rendah tidak boleh bertentangan dengan peraturan perundang-undangan yang lebih tinggi.

Sedangkan yang dimaksud dengan kekuatan hukum peraturan perundang-undangan sesuai dengan "hierarki" peraturan perundang-undangan adalah penjenjangan setiap jenis peraturan perundan-undangan yang didasarkan pada asas bahwa peraturan perundang-undangan yang lebih rendah tidak boleh bertentangan dengan peraturan perundang-undangan yang lebih tinggi. Adanya penjelasan tentang kedudukan hukum dari jenisjenis peraturan perundang-undangan di luar hierarki yang disebutkan dalam Pasal 7 UU 
Nomor 12 Tahun 2011 dilatarbelakangi oleh pemikiran mengenai praktik ketatanegaraan dan pemerintahan ditemui berbagai ketentuan yang bersifat regulatif, yang ditetapkan oleh badan/atau pejabat yang diberi kewenangan untuk itu. Harus dipahami bahwa keberadaan dan kekuatan mengikat dari jenis peraturan perundang-undangan di luar hierarki seperti disebutkan dalam pasal 7 ayat (1) adalah hanya sepanjang diperintahkan dan tunduk pada prinsip hierarki. Hal ini sesuai dengan teori hierarki perundang-undangan yang disampaikan Hans Kelsen dan Friedman, bahwa suatu peraturan yang lebih rendah tidak dapat membentuk aturan bila tidak diperintahkan oleh peraturan yang lebih tinggi.

Berkaitan dengan teori kewenangan, kewenangan didefinisikan sebagai kemampuan bertindak yang diberikan oleh undang-undang yang berlaku untuk melakukan hubungan dan perbuatan hukum. Salah satu prinsip utama yang dijadikan dasar dalam setiap penyelenggaraan pemerintahan dan kenegaraan di setiap negara hukum adanya asas legalitas. Dengan kata lain, setiap penyelenggaraan pemerintahan dan kenegaraan harus memiliki kewenangan yang diterjemahkan sebagai suatu kemampuan untuk melakukan suatu tindakantindakan hukum tertentu yang didasarkan pada delegasi dan/atau atribusi yang diberikan oleh peraturan perundang-undangan. Berdasarkan pada pembahasan di atas, maka keberadaan Permenkumham No. 23 Tahun 2018 yang dikeluarkan oleh Dirjen Peraturan Perundangundangan Kementerian Hukum dan HAM RI secara yuridis formil tidak dapat dipertanggung jawabkan, hal ini dikarenakan tidak ada satu pasal di dalam UU No. 12 Tahun 2011, Peraturan Pemerintah No. 59 Tahun 2015 tentang Keikutsertaan Perancang Peraturan Perundang-Undangan dalam Pembentukan Peraturan Perundang-Undangan dan Pembinaanya dan Peraturan Presiden No. 87 Tahun 2014 tentang Peraturan Pelaksanaan UndangUndang Nomor 12 tahun 2011 tentang Pembentukan Peraturan Perundang-Undangan, yang memberikan delegasi kepada Kementerian Hukum dan HAM untuk mengharmonisasi Rancangan Peraturan Menteri atau Lembaga.

Selanjutnya, dalam pelaksanaan pengharmonisasian, menurut sebahagian besar K/L, dalam proses pelaksanaan harmonisasi yang dilakukan oleh Kementerian Hukum dan HAM memiliki masalah sebagai akibat dari tidak jelasnya proses dan mekanisme pengharmonisasian. Hal ini dikarenakan di dalam substansi Permenkumham No. 23 Tahun 2018 tidak dilengkapi dengan mekanisme yang jelas mengenai prosedur pengharmonisasian, jangka waktu dan frekuensi dari proses harmonisasi. Selain permasalahan tersebut, faktor utama yang menghambat proses harmonisasi adalah pengulangan dalam pembahasan substansi pada saat tahapan proses harmonisasi. Artinya ketika sudah dilakukan pembahasan substansi pada proses harmonisasi di masing-masing $\mathrm{K} / \mathrm{L}$, maka pembahasan substansi dilakukan kembali pada proses harmonisasi dengan Kementerian Hukum dan HAM. Lebih lanjut, proses harmonisasi yang terpisah dengan proses pengundangan juga menjadi kendala. Berdasarkan pendapat $\mathrm{K} / \mathrm{L}$, penggabungan proses harmonisasi dan pengundangan akan memotong alur birokrasi.

\section{Diagram}

\section{Kategori Respon Kepatuhan Kementerian/Lembaga}

pada Permenkumham N0. 23 Tahun 2018

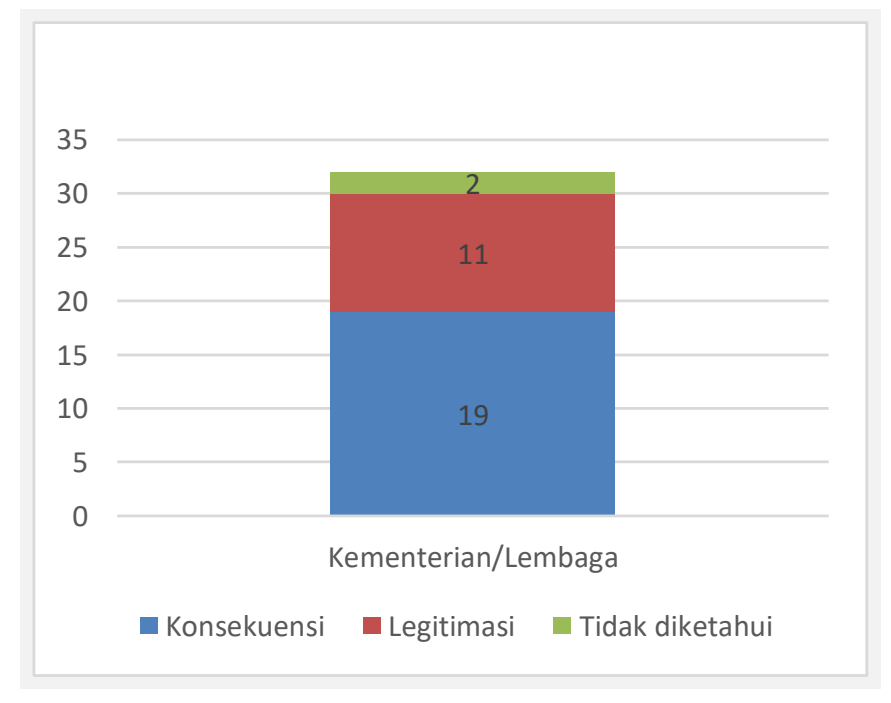

Berdasarkan diagram tersebut terlihat bahwa sebahagian besar 19 (sembilanbelas) K/L mematuhi Permenkumham No. 23 Tahun 2018 dengan alasan khawatir atas konsekuensi, di antaranya adalah tidak diundangkannya rancangan peraturan yang diajukan kepada Direktorat Jenderal Peraturan Perundang-Undangan. Konsekuensi lainnya adalah karena adanya perintah dan instruksi dari pimpinan yang memerintahkan untuk melaksanakan ketentuan Permenkumham No. 23 Tahun 2018, dan 11 (sebelas) $\mathrm{K} / \mathrm{L}$ yang menyatakan mengakui 
legitimasi Kemenkumham dan selanjutnya 2 (dua) $\mathrm{K} / \mathrm{L}$ yang tidak diketahui karena kedua $\mathrm{K} / \mathrm{L}$ tersebut tidak melakukan penerbitan peraturan Informan $\mathrm{K} / \mathrm{L}$ menyatakan bahwa setelah diberlakukannya Permenkumham ini, mereka bersedia untuk taat dengan Permenkumham No. 23 Tahun 2018 ini karena bagaimanapun mereka tetap mengakui kewenangan Kementerian Hukum dan HAM melalui Permenkumham No. 23 Tahun 2018. Tetapi mereka memberi catatan perlunya ada sosialisasi mengenai kejelasan SOP dalam melaksanakan pengharmonisasian Permenkumham No. 23 Tahun 2018 yang meliputi kejelasan tahapan-tahapan proses, kategori Permen atau Peraturan Lembaga apa saja yang diharuskan untuk harmonisasi karena terdapat usulan dari K/L bahwa tidak semua Permen atau Peraturan Lembaga perlu diharmonisasi dan mengenai frekuensi serta berapa lama waktu proses harmonisasi.

\section{KESIMPULAN}

Berdasarkan analisis yuridis normatif dan empiris di atas, maka dapat disimpulkan sebagai berikut:

1. Undang Undang No. 12 Tahun 2011, Peraturan Pemerintah No. 59 Tahun 2015, dan Peraturan Presiden No. 87 Tahun 2014, memberikan delegasi kepada Kementerian Hukum dan HAM untuk mengharmonisasi peraturan perundang-undangan sampai pada tingkatan undang-undang hingga peraturan presiden. Namun tidak memberikan delegasi untuk mengharmonisasi Rancangan Peraturan Menteri atau Lembaga.

2. Dalam pelaksanaan Permenkumham No. 23 Tahun 2018, Kementerian dan Lembaga tetap melakukan proses harmonisasi pada tahapan pembentukan rancangan peraturan di setiap $\mathrm{K} / \mathrm{L}$, dan mengharapkan kejelasan waktu dan proses harmonisasi serta pengundangan di Kementerian Hukum dan HAM dalam rangka mempercepat proses penerbitan peraturan perundang-undangan di setiap $\mathrm{K} / \mathrm{L}$ analisis harus menjawab permasalahan dan tujuan penelitian.

\section{SARAN}

Beberapa rekomendasi yang dapat disampaikan sebagai hasil penelitian, Kepada Menteri Hukum dan HAM untuk menginstruksikan:

1. Direktur Jenderal Peraturan PerundangUndangan melakukan revisi Peraturan Menteri Hukum dan HAM No. 23 Tahun 2018 tentang Pengharmonisasian Rancangan Peraturan Menteri, Rancangan Peraturan Lembaga Pemerintah Nonkementerian, dan Rancangan Peraturan dari Lembaga Nonstruktural oleh Perancang Peraturan Perundang-Undangan, dengan menambahkan kepastian atas prosedur/mekanisme dan jangka waktu penyelesaian proses pengharmonisasian Rancangan Peraturan Menteri atau Lembaga melalui pembuatan Standar Operasional Prosedur (SOP).

2. Kepala Badan Pengembangan Sumber Daya Manusia Hukum dan HAM untuk, menyelenggarakan lebih banyak pendidikan dan pelatihan Penyusunan dan Perancangan Peraturan Perundang-undangan (Diklat Suncang) bagi pegawai dari Kementerian dan Lembaga.

\section{UCAPAN TERIMA KASIH}

\footnotetext{
Dengan diterbitkan tulisan tentang "Efektivitas Implementasi Peraturan Menteri Hukum dan HAM Nomor 23 Tahun 2018 Tentang Pengharmonisasian Rancangan Peraturan Menteri, Rancangan Peraturan Lembaga Pemerintah Non Kementerian atau Rancangan Peraturan dari Lembaga Non Struktural oleh Perancang Peraturan Perundang-Undangan" di Jurnal De Jure, Badan Penelitian dan Pengembangan Hukum dan Hak Asasi Manusia, Kementerian Hukum dan Hak Asasi Manusia R.I. pada tahun 2019, penulis mengucapkan terima kasih yang sebesar-besarnya kepada: Kepala Badan Penelitian dan Pengembangan Hukum dan Hak Asasi Manusia; Kepala Pusat Penelitian dan Pengembangan Hak Asasi Manusia; Sekretariat Pengelola Jurnal Badan Penelitian dan Pengembangan Hukum dan Hak Asasi Manusia; Editor dan Mitra Bestari yang telah memberikan dukungan atas selesainya karya tulis ilmiah ini.
} 


\section{DAFTAR KEPUSTAKAAN}

A Hamid S. Attamimi, "Teori Perundangundangan Indonesia, Suatu Sisi Ilmu Pengetahuan Perundang-undangan Indonesia yang Menjelaskan dan Menjernihkan Pemahaman", Pidato pada Upacara Pengukuhan Jabatan Guru Besar Tetap pada Fakultas Hukum Universitas Indonesia di Jakarta, 25 April 1992.

A. Hamid S. Attamimi, Peranan Keputusan Presiden RI dalam Penyelenggaraan Pemerintahan Negara. Disertasi. Jakarta: Fakultas Pascasarjana Universitas Indonesia. 1990.

Anthon F. Susanto, ButirButirPemikirandalamHukum, Bandung: RefikaAditama, 2008.

Friedman, L. M., “American Law: An Introduction (Hukum Amerika: SebuahPengantar) Penerjemah: Wishnu Basuki, Jakarta: Tatanusa, 2001.

Friedman, Lawrence M, Hukum Amerika: SebuahPengantar, Cet ke-1, Edisi ke-2, (Penerjemah, Wishnu Basuki), PT Tata Nusa, 2001, Jakarta.

Hans Kelsen dalam Jimly Asshiddiqie dan Ali Safaat, Teori Ham Kelsen Tentang Hukum, Jakarta: Konstitusi Press, 2006.

I. C. van der Vlies, Buku Pegangan Perancang Peraturan Perundang-undangan (Handboek Wetgeving), Alih Bahasa, Linus Doludjawa, Jakarta: Dirjen PP Depkumham, 2005.

Indrawati, Maria Farida, Ilmu Perundangundangan, Jenis, Fungsi, dan Materi Muatan, Penerbit, Kanisius, 2007, Jakarta.

Kementerian Pendidikan dan Kebudayaan, Kamus Besar Bahasa Indonesia, Edisi Keempat, PT Gramedia Pustaka Utama, 2013, Jakarta.

SaldiIsra, Pergeseran Fungsi Legislasi, Menguatnya Model Legislasi Parlementer dalam Sistem Presidensial Indonesia. Jakarta: RajawaliPers, 2010.

Satjipto Rahardjo, Membedah Hukum Progesif. Jakarta: Penerbit Buku Kompas, 2008.

Soerjono Soekanto, "Sosiologi: Suatu Pengantar", Rajawali Press: Bandung, 1996.
Soetandyo Wignjosoebroto, "Menggagas Terwujudnya Peradilan yang Independen dengan Hakim Profesional yang Tidak Memihak", Buletin Komisi Yudisial Vol I/No 3 Des 2006.

Soeyono Soekanto, Pengantar Penelitian Hukum, Jakarta:Universitas Indonesia Press, 1982.

Sondang P. Siagian, "Kiat Meningkatkan Produktifitas Kerja”, Penerbit: Rhineka Cipta, Jakarta, 2002.

Trijono, Rachmat, Dasar-Dasar Ilmu Pengetahuan Perundang-Undangan, Papas SinarSinanti, 2013, Depok.

Wicipto Setiadi, "Continuing Legal Eduacation (CLE): Instrumen Pemerintahan", Pusat Penelitian dan Pengembangan Sistem Hukum Nasional, BPHN, 2011.

Agus Sahbani, Permekumham tentang Harmonisasi Peraturan Dinilai Konflik dengan UU, https://www.hukumonline.com/berita/baca/l t5bdc39c5d3a98/permenkumhamharmonisasi-peraturan-dinilai-konflikdengan-uu, diakses pada tanggal 6 Januari 2019.

Putusan MAHKAMAH AGUNG Nomor 71 P/HUM/2018 Tahun 2018, https://putusan.mahkamahagung.go.id/peng adilan/mahkamah-agung/direktori/tun/hakuji-materiil/,diakses pada 23 Januari 2019.

Undang-Undang Dasar 1945.

Undang-Undang Republik Indonesia Nomor 12 Tahun 2011 tentang Pembentukan Peraturan Perundang-Undangan.

Peraturan Pemerintah Nomor 59 Tahun 2015 tentang Keikutsertaan Perancang Peraturan Perundang-Undangan dalam Pembentukan Peraturan Perundang-undangan dan Pembinaannya.

Peraturan Presiden No. 87 Tahun 2014 tentang Peraturan Pelaksanaan Undang-Undang No. 12 Tahun 2011 tentang Pembentukan Peraturan Perundang-udangan. 